In fact, the lens of the highest objective is enclosed in a brass capsule which is perforated on either side, the perforations measuring about $1 / 25$ of an inch in diameter. With the highest power there is an extraordinary working distance-one eighth of an inch. The maximum magnification, by the way, corresponds roughly with that of a modern Leitz microscope, having a No. 6 objective and No. 1 eyepiece.

The accessories include stage-forceps, a small bull's-eye condenser, a hand lens, forceps, extra concave mirror, a long handle (?), a plano-concave lens, and ten objects mounted dry in sockets in a wheel-like carrier. The objects are still in place and include pollen, flea, wing of fly, spider and insect scales.

Bashford Dean.

\title{
STOMATOLEPAS, A BARNACLE COMMENSAL IN THE THROAT OF THE LOGGERHEAD TURTLE
}

While investigating the parasites of the loggerhead, $C a$ retta caretta, at the Marine Laboratory of the Carnegie Institution at Tortugas, Florida, Professor Edwin Linton found numerous small barnacles partially imbedded in the mucous membrane of the upper end of the gullet. Many sessile barnacles are known to live externally on marine turtles, whales, etc., but up to this time none has been known living internally. ${ }^{1}$ One group of Cirripedia, the Rhizocephala, consists wholly of parasitic forms which penetrate their crustacean hosts through the external integument. The barnacle discovered by Professor Linton which we will call Stomatolepas, seems to be the first commensal form of the thoracic cirripedes.

Stomatolepas has about the size and shape of a split pea, the oral surface being flattened. The calcareous walls form a shallow bowl which is imbedded about half of its depth in the membrane of the gullet or posterior part of the mouth of the host.

\section{Stomatolepas prægustator n. sp.}

The walls form a very broad, shallow cup, nearly circular in contour, and about twice as wide at the opening as at the base. The base is flat, circular, excessively thin, but sufficiently calcified to be rigid and retain its shape when dried. The plates of the wall are composed of two layers, an inner layer, thin, dense and transparent, and an outer covering of several layers of thin-

1 The stalked barnacle Dichelaspis lives in the gill cavities of crabs, but is not truly parasitic or commensal. 
walled cells. Externally a shallow radial sulcus in the cellular surface marks the sutures between the plates. Each plate has a triangular smooth median area at the base, where the outer cellular layer is lacking, and the arched projecting upper ends of the plates also lack the cellular layer. The summits of the rostral and lateral plates are broader than the bases and strongly arched; the cardinal plate projects less above the cellular
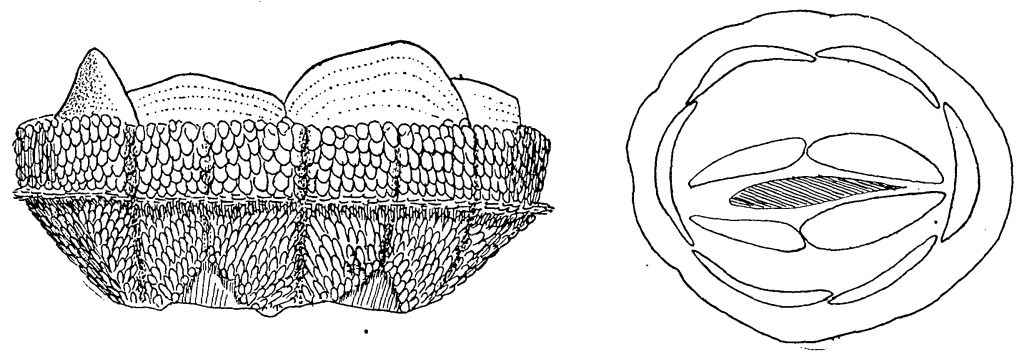

Fig. 1. Stomatolepas pragustator, lateral view and diagram of the oral face.

layer and is lower than the others. Internally the plates of the wall are glossy, show no sheath, and are transversely ridged, the ridges very narrow, parted by wide smooth intervals and about twelve to fifteen in number; the basal fourth or third of each. plate is smooth.

Length of the walls 6.7 , diam. 6 , height $3 \mathrm{~mm}$.

The opercular plates protect less than half the area of the orifice, are very thin, glossy, white and smooth both outside and within. They are long and narrow, the terga in contact with the scuta but not articulated or interlocking in any way. The scuta are longer than the terga, tapering to a point at the rostral end, rounded at the tergal end.

The cirri are rather short. The first has unequal rami of 8 and 12 segments; the rest have subequal rami, the sixth pair having 20 and 22 segments. The segments are armed with two pairs of long spines, and on some of the median segments a third extremely minute pair. Posteriorly there is a pair of small spines at the distal angle of. each segment.

The penis is about as long as the cirri, very densely annulate, bearing very few minute hairs. There is a dense terminal pencil of very short hairs.

The mandible has four large spines and a blunt, multispinose lower angle. The maxilla has two large spines above followed by a small notch, below which there are 7 to 10 spines.

Stomatolepas belongs by its non-articulated scutum and ter- 
gum to the subfamily Coronulinæ as defined by Gruvel, ${ }^{2}$ being most closely related to the genera Tubicinella Lam., which lives on the skin of whales, and Stephanolepas Fischer, a barnacle which lives imbedded in the plates of Thalassochelys imbricata. Both of these have the wall more or less tubular and conspicuously annulated externally. In Stomatolepas the wall is depressed and broadly bowl-shaped, and covered externally with a mass of thin-walled cells.

Henry A. Pilsbry.

\section{THE AGE OF SPEED SIRES}

The contribution by Professor F. R. Marshall in Tre AmeriCAN Naturalist for January, 1909, on the age of speed sires, escaped my notice until recently called to my attention. In that article Professor Marshall refers to the fact that I found the average age of trotting sires to be 10.43 years, and that by taking all sires in four generations of ancestors of $2: 10$ trotters I found the average age at approximately 14 years.

Professor Marshall objects to this comparison as not being a fair one on the ground that by going back four generations from our 2:10 trotters we go back into the formative period of the breed. This formative period, he asserts, followed the descent from Hambletonian 10, foaled in 1849, and involved his sons, which were used largely in the stud until old age. This he holds produced an abnormal number of old sires at that period of history, and that by including them in my tables I was drawing unwarranted conclusions from what was a mere incident. This he reinforces by showing that the immediate sires of 242 trotters in the $2: 10$ list were of the same age that I found for the normal breeding age of 1,000 cases.

In this matter Professor Marshall labors under a misapprehension. The average age of 10.43 years for sires which I found was the average as it existed in the "formative period" from 1840 to 1890 . The "Register" from which they were taken was published in 1892 and contained an alphabetical list of all standard horses from the earliest date up to immediately before 1892 . The tabulation was taken alphabetically from the index and the 10.43 is an accurate representation of what occurred when the grandsires, great-grandsires and great-great-grandsires of our $2: 10$ trotters were living and being bred.

There is, in this matter, food for profound thought, and, with2 "Monographie des Cirrhipèdes on Théeostracés," pp. 9, 270. 